Revista Iberoamericana. Vol. LXVI, Núm. 191, Abril-Junio 2000, 279-298

\title{
LA NACIÓN IMAGINARIA DE LOS ESCRITORES JUDÍOS LATINOAMERICANOS
}

\author{
POR \\ LEONARDO SENKMAN \\ Universidad Hebrea de Jerusalén
}

La represión autoritaria y violación de los derechos humanos en los países del cono sur latinoamericano legaron a la redemocratizada vida pública y sociedad civil una profunda revisión del lugar de la memoria. Memoria y olvido se constituyeron en objeto de políticas sociales de las restauradas democracias en América Latina para medirse con los legados del autoritarismo y los desafíos abiertos de reconstrucción de culturas no autoritarias. Este proceso que subvertió la relación con el pasado, el presente y el futuro, empezó a ser tema de investigación para recuperar un nuevo sentido a la articulación entre historia nacional y la memoria de sus ciudadanos. ${ }^{1}$

En cambio, muy poco se avanzó en el análisis del lugar que ocupa la memoria en la obra de narradores a quienes el exilio los dejó huérfanos del sentido tradicional que conferían a su experiencia histórica.

Este artículo, precisamente, intenta indagar en la pasión memorialista de algunos escritores judíos argentinos en su esfuerzo por inventar otras representaciones de la historia de sus países, al descubrir que su temporalidad nacional se desestructuró y el sentido del futuro quedó fuera de la órbita del presente.

El exilio que arrojó de las dictaduras latinoamericanas a miles de intelectuales lejos de sus patrias, afectó profundamente la relación de los judíos con los lugares de la memoria: ${ }^{2}$ al retomar el cayado de apátridas,algunos descubrieron que otros éxodos de sus ancestros ya los habían precedido en el destino de errantes empedernidos. Los años setenta fueron decisivos en sus vidas personales, y cruciales en la dolorosa percepción de vivir en una diáspora que hasta entonces sólo era recordada como el "fuera-de-lugar" de sus abuelos

\footnotetext{
${ }^{1}$ Ver el debate intelectual para el caso argentino, uruguayo y brasilero en torno a la relación memoria - historia-olvido-perdón sobre el pasado autoritario reciente a propósito de la necesidad de reconstrucción de la cultura (Saúl Sosnowski, Represión y reconstrucción; Represión, exilio; Brasil); sobre la discusion de construir una memoria colectiva desde la herida abierta por los familiares de los desaparecidos y víctimas de la represión, Elizabeth Jelin ("The Políticas of Memory”); sobre la articulación de memoria social e historia nacional, los artículos de Hugo Vezzeti; Hilda Sabato.

${ }^{2}$ Utilizo el marco conceptual de "lugares de la memoria” según Pierre Nora; ver una lúcida crítica histórica a los riesgos de la pasión memorialista de los usos de este marco conceptual en Oliviere Mongin ("Une memoire"). Una excelente intepretación de las políticas de la memoria y el olvido durante los primeros años de retorno de la democracia en la Argentina en Luis Roniger y Mario Sznajder.
} 
inmigrantes. Nunca antes se imaginaron que estarían obligados a desandar, desde el entrañable sur latinoamericano natal, las rutas del destierro que transitaron padres, abuelos, tatarabuelos y bisabuelos emigrantes.

La literatura del exilio escrita por algunos escritores judíos latinoamericanos ha generado estrategias narrativas y poéticas trabajadas por la memoria autobiográfica que se diferencian de otras similares del género. En primer lugar, se caracterizan por formar parte de memorias colectivas, y no sólo individuales, que se remontan en el tiempo a través de varias genealogías familiares, más allá de su propia generación, franqueando espacialmente las fronteras nacionales de sus países sudamericanos. En segundo lugar, el exilio forzado provocó, además, que la memoria colectiva redescubierta difiriera y se alejase del discurso conocido de las narrativas de la historia nacional de sus patrias natales. Ciudadanos de segunda y tercera generación e hijos nativos de inmigrantes, durante años habían estado mucho más ansiosos por conocer la memoria colectiva de sus repúblicas, según las públicas narrativas nacionales, que hurgar en la memoria colectiva y privada de sus familias y ancestros. Pero desde el momento en que la represión les hizo descubrir que los extranjeros ya no eran los "Otros", sino ellos mismos transformados ahora en extranjeros en tierras de exilio, sintieron la imperiosa necesidad de conocer aquellos antiguos éxodos de sus ancestros mientras desandaban el camino inverso. En tercer lugar, esta literatura autobiográfica les sirve no sólo para conocer la "otra historia", sino para comprender mejor la antigua sospecha de que el vínculo con "su pasado" no necesariamente converge con "la historia” de la Nación.

Esos escritores judeo-latinoamericanos habían aprendido de la historia oficial de la Nación a representar el pasado común colectivo en un tiempo cronológico, continuo y homogéneo, y se ilusionaron durante mucho tiempo por el relato optimista de esas narrativas de que el futuro de todos los ciudadanos estaría ligado inescindiblemente al pasado de la Nación. Súbitamente, el exilio les hizo perder con dolor las ilusiones retóricas sobre el “destino nacional” al comprobar que, ante todo, habían perdido la Nación. Por primera vez, su reflexión sobre el pasado colectivo se hizo perentorio más allá del discurso de la historia nacional, que había despertado tantos afanes para incorporarse como ciudadanos sin diferencias de origen religioso. Pero ni bien el exilio los convirtió en extranjeros, una mirada más profunda sobre los mitos del pasado nacional, los dejó perplejos al comprender angustiosamente que como ciudadanos exiliados se habían quedado sin presente, pero también sin pasado: se hizo añicos la ilusión de que existía una relación causal entre el pasado de sus países y el futuro de sus ciudadanos.

El acto de escribir se desencadenó en el preciso instante que buscaban la palabra para nombrar la fractura entre el estado-nación que los exiliaba y su escamoteado origen.

Gracias a su escritura, pudieron desbloquear la lógica representativa de la tradición literaria nacional basada en un continuo histórico, que fue reemplazado por el imaginario del desvío, el viaje, la errancia y el salto temporal. Desde este desvio fundamental que significó el exilio, algunos intelectuales decidieron conocer cuáles fueron los momentos negados, desplazados y ajenos de aquél otro pasado que los constituía desfasadamente como latinoamericanos judíos: se preguntaron quiénes eran los “Suyos” y quiénes los “Otros”, y de qué manera era posible deslindar la reconstrucción de su memoria colectiva 
familiar y étnica de la línea sucesiva de la historia nacional. La indagación sobre el origen remitió a estos exiliados a la cuestión nada retórica de su identidad.

Ana Vásquez Bronfman, escritora y psicóloga chilena exiliada en París, escribió cómo descubrió en el exilio esa no coincidencia entre su historia nacional y el pasado judío, la fisura entre “los nuestros y los míos”. Dice en uno de sus textos autobiográficos:

Compartiendo la tragedia que en esta larga errancia nos narramos insaciablemente, los
laberintos de mi pasado han ido surgiendo bajo otras luces: si no he vivido la ruptura como
un drama, ha sido porque he tomado conciencia de otros exilios que ya estaban en mí,
incluso antes que naciera...Exilio de mujer que se entronca, para mí, en otro más antiguo.
Mi linaje es el de los rechazados, el de los perseguidos, el de los condenados a la huida....En
mí se condesan las Bobes humildes y los Zheides barburdos de voz ronca, que cruzaron
el océano para que por lo menos nosotros viviéramos sin miedo...Pero un exilio se injerta
en otro, una desilusión demuele la otra... He descubierto que el camino de mi exilio no
confluye totalmente con el de los otros, los nuestros no siempre son los míos...” (Vásquez,
"De rupturas” 61, énfasis mío).

A diferencia de otros textos psicológicos, es en la obra de ficción escrita en el exilio donde mejor expresa Ana Vásquez esa no coincidencia entre los "nuestros y los míos". Sorprende que en una obra científica como Exils Latino-Americains: La Malediction d’Ulysse, la psicóloga social no incorpore la dimensión judía de su pasado (o la de algunos exiliados entrevistados) cuando aborda cuestiones teóricas como exilio y herencia, los avatares de la identidad exiliada o los mecanismos de la transculturación. En cambio, Ana Vasquez Bronfman transforma el malestar de sentirse diferente por el prejuicio antijudío de algunos compañeros en el centro de la narración de su novela Mi amiga Chantal. Sus ficciones se nutren del descubrimiento en el exilio de una identidad conflictiva y en constante reconstrucción que recupera eso que denomina “la memoria de los míos”. En la novela inédita Las jaulas invisibles, por ejemplo, la patria lejana de su familia de principios de siglo en Kishinev se le mezcla con Santiago de Chile, imaginándose aquélla huída de sus padres y abuelos de Rusia como el exilio “de los míos” que había precedido muchas décadas antes su propia fuga del régimen de Pinochet. ${ }^{3}$

Desde el exilio forzoso o voluntario, desconfiados de la historia nacional, perplejos ante un pasado vuelto irreconocible, y sorprendidos de repetir al igual que sus abuelos la experiencia de ser extranjeros,los más talentosos de estos escritores decidieron acometer la enorme empresa de reconstruir su propio pasado a nivel personal, familiar,étnico y cultural, pero sin el super-yó vigilante de las narrativas de la memoria nacional en las que siempre habían creído. Fuera de la memoria nacional de la República liberal de los demócratas universalistas y heterófobos o, peor aun, desalojados de la memoria del Estado Católico autoritario y xenófobo, los escritores abandonaron la idea de una sucesión temporal homogénea con el fin de mostrar la inestabilidad, la heterogeneidad y las diferencias del pasado.

\footnotetext{
${ }^{3}$ En el capitulo III de su novela inédita Las jaulas invisibles, se narra la más remota imagen de la memoria del padre sobre el pogrom de Kishinev y la huída a la Argentina a través de la J.C.A , antes de pasar a residir en Chile. No casualmente el relato se cierra con una aguda reflexión "sobre el ser judío”.
} 
No obstante, o acaso precisamente por haber logrado zafarse de las interdicciones puestas por su identidad ciudadana, esos intelectuales judíos pudieron sentirse más libres en el exilio para recordar cómo imaginaron la Nación sus abuelos y sus padres,pero también ellos mismos cuando aún creían estar integrados para siempre en el estado-nación.

Dolorosamente, esta reconstrucción imaginaria pudo ser escrita cuando los escritores soltaron amarras de la historia de la Nación,y desde esos momentos de ruptura y transgresión se propusieron el rescate íntimo de la memoria autobiográfica y colectiva de sus ancestros. Perdidos los referentes cívicos de la lógica representativa de la tradición nacional, y lejos de los lugares de la memoria de la sociedad civil, algunos escritores judíos latinoamericanos exiliados sintieron vivir por primera vez en la diáspora. Desde el desvío y la errancia, ya no creyeron más en el espejismo de una sucesión continua y lineal de la historia. A bordo de la memoria colectiva, emprendieron travesías imaginarias por tiempos discontinuos, y en el periplo de sus viajes del exilio real cruzaron continentes y océanos salteando cronologías ordenadas, atravezando países y comarcas de emigracion de sus padres cuyos nombres sonaban extraños en su infancia, tan extraños y desprestigiados como sus lenguas dialectales que los avergonzaba en la calle porque les hacían sentirse “Otros” frente a sus conciudadanos.

Al fin libres de la autoritaria subordinación de la memoria de su pasado hacia el estadonación expulsor, estos escritores judíos también tomaron distancia de la identidad nacional al transformar la tradición en una dialéctica de la pregunta y la respuesta en su exploración por otras memorias colectivas. El resultado es una original escritura donde es posible hacer una lectura sincrónica y retrospectiva del pasado, a través de travesías por inimaginadas historias colectivas de "los míos” que se apartan del cánon dictado por la diacronía nacional. Es en la voluntad de desvío de esta transgresión escrituraria, por la cual la sincronía del exilio se vuelve al pasado para cuestionar la diacronía de la Nación, ${ }^{4}$ donde hay que inscribir la libre revaloración de la identidad judía de esos escritores; pero también es en los recodos de este desvío donde hallamos el original acceso y selección creativa del legado del judaísmo, tanto de su acervo religioso, historia, cultura, mitos, como de su lenguaje simbólico y ritos conmemorativos. Tal revaloración de lo judío de parte de escritores exiliados resulta muy significativa, ya que es producto de su trabajo con la palabra y del “estado de memoria” que les hace descubrir la existencia de lugares de la memoria colectiva,

\footnotetext{
${ }^{4}$ Refiriéndose al modo en que la vanguardia intenta leer los momentos negados y desplazados de la tradición literaria nacional, Haroldo de Campos (63) afirma la necesidad del constante y renovado cuestionar de la diacronía por la sincronía.

${ }^{5}$ Véase Tununa Mercado. Aún está por hacerse el análisis del corpus literario producido durante y luego del terrorismo de estado argentino desde el exilio exterior o interior. En este corpus se desataca un importante conjunto de autores judeoargentinos que escribieron textos "en estado de memoria". A título sólo enunciativo, ver el ciclo de las novelas de la memoria de Pedro Orgambide El arrabal del mundo, Hacer la America y Pura Memoria; Arnoldo Liberman, Grietas como templos.Biografia de una identidad; Humberto Costantini, En la noche y su texto inédito Rapsodia de Raquel. Liberman; Antonio Brailovsky, Identidad;Gerardo Mario Goloboff, Criador de Palomas, La Luna que cae, El soñador de Smith,Comuna Verdad, Sergio Chejfec, Lenta biografía; Ricardo Feierstein, Mestizo; David Viñas, Cuerpo a Cuerpo; Alicia Dujovne Ortiz, L'Arbre de la Gitane; Nora Strejilevich, Una sola muerte numerosa.
} 
los cuales habían sido desplazados (o fueron olvidados) por los lugares de la memoria nacional. ${ }^{5}$

Uno de los descubrimientos más catárticos durante el exilio fue la memoria del no lugar de los desaparecidos judíos durante el exterminio nazi. Agobiados por el dolor de tantos camaradas desaparecidos y por el luto de amigos asesinados, el rescate de la memoria colectiva durante los setenta y los ochenta les ayudó a hacer el duelo al margen de los rituales de rememoración de la memoria nacional: excluídos de ella, la recuperada memoria colectiva de "los míos" les brinda por primera vez otros ritos conmemorativos. Así, algunos escritores judíos descubren los nombres y rostros de muertos sin sepultura a quienes inhuman del genocidio europeo familiar para enterrarlos en la tumba de una nueva memoria identificatoria. La mejor literatura del exilio de escritores judíos erige ese memorial más allá de la intimidad de su comunidad étnica-religiosa, para abrirlo al espacio público del dolor latinoamericano. Por primera vez, y casi treinta y cinco años después de Auswitch, esa literatura busca escribir una memoria compartida con otros deudos, recuerda otras víctimas también desaparecidas y las inscribe en un epitafio común para el recuerdo de "los nuestros".

Un ejemplo paradigmático es el uso de figuras emblemáticas del Holocausto con las que los escritores judíos resemantizan, in memoriam, a los desaparecidos y víctimas sin sepulturas de naciones latinoamericanas.

Es el caso de Marjorie Agosín, chilena exiliada en los EE.EU y nieta de un abuelo austriaco refugiado del nazismo, quien luego del golpe de Pinochet recupera el diario de Ana Frank como el lugar de la memoria para dialogar con sus desaparecidos (Dear Anne Frank).

Otro caso es el dramaturgo y escritor uruguayo Mauricio Rosencof, ex dirigiente de la organización guerrillera Tupamaros y prisionero con confinamiento absoluto entre 19721985 durante la dictadura militar de Uruguay. Luego de su liberación,escribió Memorias del calabozo en colaboración con otro compañero de prisión para testimoniar el milagro de haber podido sobrevivir trece años de total reclusión. Pero varios años después, Rosencof acudirá a otra memoria colectiva, la de su familia polaca asesinada bajo el nazismo, para resemantizar el drama uruguayo en su narración Las cartas que no llegaron (M. Rosencof, “Las cartas que”, Die Briege). ${ }^{6}$

Pero también es el caso de varios escritores argentinos que acudieron a sus memorias familiares, como Marta Oliveri. En su novela onírico-poética Memorias del ángel caído interroga a la historia de su abuelo — poeta húngaro- que sobrevivió Buchenwald, haciendo una lectura sincrónica y retrospectiva del pasado familiar para narrar el modo en

\footnotetext{
${ }^{6}$ Un ejemplo paradigmático de su estética libertaria es la pieza teatral de Mauricio Rosencof $Y$ nuestros caballos serán blancos; ver el testimonio de Rosencof sobre la resistencia durante su confinamiento absoluto y su confianza en el poder de los sueños de libertad para su recreación teatral en la obra citada del legendario Artigas bajo prisión del dictador paraguayo Dr. Francia, "Literatura de Calabozo", en Saúl Sosnowski (comp). Un fragmento de Las Cartas que no llegaron fueron publicadas en Marcha (Montevideo, 20 junio 1995). Citamos de la traducción al alemán, cuya publicación precedió a la edición en español. Ver la reseña bibliográfica a la edición alemana de Anastasia Telaak en NOAJ. En una entrevista personal con el escritor, Rosencof recordaba que durante las visitas periódicas de su padre a la cárcel, a menudo le recordaba el destino de su familia en la Varsovia ocupada por los nazis (Entrevista en Berlin, mayo 1995).
} 
que sobrevivió durante los años siniestros de la dictadura,así como también relata su lucha por sobrevivir a la banalidad de la amnesia social de los argentinos que retornan a vivir en democracia.

Algunos escritores judeo-argentinos han producido un corpus narrativo y poético totalmente singular de literatura del exilio, aún no estudiado por la crítica,en el que se resemantiza desde la expulsión de los judíos españoles, el idioma ladino y el gran legado cabalístico sobre el destierro y la redención (Antonio E. Brailovsky, Identidad; Juan Gelman, Dibaxu, Interrupciones I y II), hasta la condición errante y nomada del judío en el siglo XX y sus dilemas de identidad (Luisa Futoransky, Partir, Son cuentos, De Pe, La Sanguina, Formosa; Elina Wechsler, El fantasma, La larga marcha, Mitomanías, Progresiones) ${ }^{7}$

\section{FRAGMENTACIÓN DE LA NACIÓN E HIBRIDIZACIÓN DE LA IDENTIDAD NACIONAL}

El árbol de la gitana de Alicia Dujovne Ortiz es un texto que condensa los más importantes incisos de la literatura de exilio y su necesidad de inventar una memoria colectiva. Novela de la pérdida de las fronteras nacionales, narrada por la hija, es también la saga de los padres que imaginaron la nueva patria de sus sueños y utopías y le legaron a Alicia el mandato filial de escribir esa historia. Pero, al mismo tiempo, la novela es la cartografía de una geografia descubierta donde los antepasados exiliados de la narradora deambularon con una memoria familiar a cuestas que no coincide con la historia nacional. Relato urdido con genealogías, el texto de Dujovne Ortiz se propone en clave paródica desentrañar el sentido de una identidad familiar forjada a través de cruces étnicos y mezclas culturales en el Nuevo Mundo. En esta dirección, El árbol de la gitana acomete una aventura que pocas novelas del exilio argentino emprendieron: nos descubre con humor les lieux de memoire de varias estirpes híbridas y confluencias de antepasados que cruzaron ida y vuelta las fronteras de la patria.

La escritura del exilio ha mostrado a menudo cómo la Nación se volvió irreconocible para los que finalmente lograron regresar a casa. En cambio, pocas veces nos revela cómo el desterrado inventa el pasado de su Nación a partir del momento de haberla perdido. Pero además la novela de Dujovne Ortiz narra la posibilidad de esa invención a través del legado de historias fragmentadas que tantas veces oyó contar a sus padres y que la hija desde el exilio creyó un mandato contarlas con ayuda de su ángel de la guarda.

Mucho menos importante que el recuerdo de su expulsión de la Buenos Aires militarizada de 1977, la memoria de la narradora desencadena el relato en el exilio parisino a partir de la cadena de pérdidas familiares y de los numerosos lugares ausentes. Desde la pérdida de los barcos de su tatarabuelo materno o del bisabuelo paterno, que casi perdió la

\footnotetext{
${ }^{7}$ Recientemente ha sido abordado por la crítica la memoria judía del exilio de Juan Gelman en el poemario Com/posiciones, que reúne poemas traducidos, antologados y re-escritos por el autor , en particular las composiciones de Gelman en base a su lectura de poemas del exiliado poeta judeoespañol medieval Yehuda Halevy. Véase María del Carmen Sillato "Com/posiciones”; Leonardo Senkman "Entrevista a Juan Gelman” y el poemario de Gelman Dibaxu escrito en judeoespañolladino.
} 
vida en un pogrom, hasta la decisión de su hija cuando decide irse a vivir con el compañero colombiano para buscar sus raíces en el Amazonas.

La convivencia en París con otros exiliados del Este Europeo indudablemente le ayudan a Alicia a tomar conciencia que no solamente ella había perdido sus íntimas referencias geogróficas y nacionales. Sin embargo, frente a esos exiliados de Rusia, Hungria y Bulgaria, la exiliada de la Argentina sentía que siempre había vivido en un país imaginario fundado por inmigrantes europeos. Mientras que sus amigos europeos no dudan que sus ancestros vivieron desde siempre a orillas de los grandes ríos; en contraste, Alicia siente que nunca tuvo ninguna geografía propia y hasta duda si los ríos hogareños no habrían sido meramente imaginarios (144):

Katalin, ¿era de Besarabia o de Moldavia mi familia paterna? ¿Cómo se dice: Moldavia o Besarabia? Trata de comprender la estafa que me han hecho privándome del Dniester, o del Dnieper, yo qué se cuál de los dos, y encajándome a cambio ese Río de la Plata que sólo sirve para irse. Exiliada, sí, pero de nacimiento, porque soy argentina .... Yo nunca comprendí qué estaba haciendo no te digo en Chichy: en Buenos Aires! Por eso se me saltaban los ojos de pura perplejidad (152-153).

Literatura del destierro, la estrategia narrativa de Dujovne Ortiz avanza en varios tiempos históricos y atraviesa los espacios imaginarios de quien fue despojada de su tierra. Los quince capítulos de la novela se encabalgan en un vaivén narrativo que tiene la estructura de un viaje de ida y vuelta, ininterrumpidamente,desde la patria desterritorializada al árbol genealógico familiar.

El proyecto autobiográfico de Alicia se instala en las antípodas de la literatura de la memoria colectiva de la Nación: por el contrario, su punto de partida es la desintegración de esa memoria nacional, el naufragio de la historia de esa memoria y el esfuerzo por aferrarse a un relato del origen que reemplace a la pérdida de su patria. A diferencia de otros escritores exiliados que buscaron desde lejos deconstruir y reconstruir su pasado nacional, a ésta desterrada judeoargentina en París no le interesa rescatar los fragmentos de los lugares de la memoria de su solar natal con el fin de tornarlo más reconocible. Más bien, la narradora de El árbol de la gitana se complace en trazar una cartografía de los lugares del pasado de su genealogía: no los sitios ciudadanos de la Nación. Y si se interna a menudo en los territorios simbólicos de la memoria nacional para relatarnos paródicamente la memoria colectiva de sus esferas públicas, es con el único propósito de inventarse una toponimia familiar. El trabajo de la memoria colectiva, pues, se desliza hacia un atajo a través del cual la narradora se da cita con fragmentos de otras memorias ancestrales capaces de hacerle comprender su actual perplejidad en el destierro. Faena nada sencilla: construirse el árbol genealógico desde su intransferible biografía familiar sin ayuda de la historia para remontar más de nueve siglos, y bastarse sola con la irreverente selectividad de sus recuerdos. Al subsumir la historia nacional en la memoria familiar, el pasado unívoco de la Nación se desvanece, y sólo surge inventado como si fuere un relato paródico del Estado-Nación a través de sus discontinuidades temporales y dislocaciones espaciales. Una lectura significativa de El árbol de la gitana, precisamente surge del desopilante relato de cómo se había imaginado los lugares de la Nación, una narradora cuya escritura se desencadena a partir del 
momento de sentir que la perdió. A diferencia de otros narradores del exilio que perdieron casi toda memoria del pasado, desde su destierro Alicia no tiene que luchar demasiado con ninguna amnesia, ni le cuesta tampoco recordar cuáles son los restos supérstites de la memoria colectiva. Ni siquiera le preocupa confrontar la historia oficial de la Nación con los ramalazos de sus recuerdos personales. Descubriendo las raíces de su árbol genealógico, Alicia se divierte al comprobar cuán discontinua resulta la historia nacional, y nos sonreímos con ella al constatar cuán diferente surge esa historia comparada al modo en que había sido imaginada por su familia. Sin proponérselo, esta humorada paródica sobre el exilio roza un tema muy serio: el divorcio entre historia nacional y memoria colectiva. No sólo surgen patentes las discontinuidades de la historia patria, sino también el relato desplaza del centro de gravedad de la identidad colectiva al Jus Solis, ese fundamento territorial omnipresente del estado-nación sudamericano. El entramado de la memoria familiar descubre un primordialísimo fuera de lugar, la tierra de nadie, localizada en las comarcas imaginarias al interior y exterior de Argentina, y donde toda sociedad civil se diasporiza. A través de la memoria cartográfica, este relato pone en cuestión el consenso de las narrativas nacionales en su intento de homogeneizar todos los territorios de la patria, sean materiales o imaginarios. En este sentido, el libro de Alicia Dujovne Ortiz se lee en el revés de la trama de aquellas narrativas que instauran un orden fundante del civismo nacional de la República. Así, en lugar de la uniformidad territorial el relato sobre la vida social transcurre cruzando fronteras; la más completa heterogeneidad pulveriza la pretendida homogeneidad del ser colectivo, y en donde se esperaba una continuidad de antepasados comunes, sorprenden las mezclas étnicas culturales y religiosas. Los lugares de la memoria de esta novela se despliegan en la diferencia, no en la asimilación; y en los márgenes sus seres nómadas expresan numerosas lealtades de en vez de la exclusiva ciudadanía al estado, celebrando la convivencia con tradiciones culturales diversas y plurales a pesar de la heterofobia nacional del crisol de razas.

De modo emblemático, el árbol genealógico de la novela es una metáfora biológica que connota el origen y la herencia: no la historia. La única certeza que le queda a la exiliada judeoargentina en París es instalarse en las ramas de sus genealogías paternas y maternas que se injertaron en un árbol que creció con brotes transplantados. Esta es la divisa que atraviesa toda la narración. No sólo carecen de blasones familiares: la errancia de sus protagonistas y las mezclas de sus ramas patrilineales y matrilineales forman un árbol que crece hacia lo alto porque nunca tuvo tierra. "Entonces, el reflejo del árbol de nuestras idas y venidas tendrá las ramas en la tierra y las raíces en el cielo” (152).

Sin orígenes claros, la única certeza sobre sus ascendientes es imaginarlos oriundos de mezclas, simulaciones y clandestinidades. La familia paterna de Akiba Dujovne, que habitaba Besarabia y Moldavia, es imaginada proveniente de antepasados jázaros, esos tártaros convertidos al judaísmo que levantaron un reino en la Crimea del siglo IX, mientras que la familia genovesa materna provenía de descendientes de criptojudíos.

¿Los jázaros eran conversos? ¿Los españoles eran marranos? Tanto mejor. Me da lo mismo ser judía por la derecha o por la izquierda (156). 
Efectivamente, hay una metáfora existencial que asciende y desciende continuamente por el árbol genealógico: judía. Única certeza en medio de tantas incógnitas durante su exilio parisino. Pero también la única identidad que se le ocurre para nombrar a esa condición humana de ser no sólo hija de mezclas en un mundo nómade, sino también para hablar del fracaso de no haber podido vivir la sedentariedad en su propia Nación.

Los relatos de linajes de los Oderigo y Ortiz, vía materna, y de los Dujovne vía paterna, se cruzan en un árbol genealógico plantado no en tierra firme sino en la ribera de ríos que fluyen permanentemente y donde sus ancestros nacidos de mezclas en los albores de la nacionalidad argentina, se territorializan y al mismo tiempo se desapegan. Esta alternancia ritma la narración y cautiva la lectura de las insólitas conexiones de tan diferentes genealogías e inauditas fragmentaciones.

El linaje materno de la narradora es paradigmático. Conocemos más el relato de sus antepasados que la biografia de su madre. Esta desciende de genoveses y españoles que se remontan al legendario Micer Nicolo Oderigo, jurisconsulto de la banca San Giorgio en Génova y embajador de su república ante los Reyes Católicos. Ese genovés, apoyó fervientemente el viaje de Colón aunque se sorprendiera de que el descubridor, en realidad buscara las mitológicas diez tribus perdidas de Israel. También Oderigo, que tenía intereses comerciales en Crimea, se sorprendió al tener noticia de los Jázaros en cuyo medio va a encontrar por azar a uno de los antepasados paternos de la narradora. Oderigo es el puente entre los lugares de la memoria familiar de la narradora, tanto en Jazaria donde se topó con Samuel Dujovne como en la toma de Granada donde conoció a Don Pedro de Vera.

Siglos después, en 1826 llega a la Argentina el navegante y comerciante Giuseppe Oderigo, descendiente de aquel Micer Nicolo. Este genovés había venido al Río de la Plata invitado por Rivadavia para crear una flotilla fluvial que navegara entre Buenos Aires y Asunción con el fin de abrir la navegación de los ríos; pero el dictador paraguayo Gaspar Francia le hizo dudar, en nombre del proteccionismo nacionalista, si debía abrir las fronteras a los europeos. En cambio, Manuel Ortiz, descendiente de ávidos conquistadores y dueño de miles de hectáreas, finalmente regala a los inmigrantes todas sus tierras en Entre Ríos, decepcionado porque sus hijos criollos abandonaron los campos. Los Ortiz eran una rama mozárabe de la familia materna, españoles de Toledo que desde el Alto Perú llegaron a Salta y de allí se instalan en Entre Ríos como grandes estancieros llamados Ortiz Vera y Mujica. Una descendiente de Nicolo Oderigo se casará en Entre Ríos con un Mujica. Samuel Dujovne, el abuelo judío agricultor que fue traído de Besarabia a Entre Ríos por la JCA, la empresa europea de colonización agrícola judía en Argentina, al poco tiempo de convivir con los gauchos judíos también abandonara el campo porque no puede soportar la inmensidad de la pampa. Ambos ascedientes de Alicia desaparecerán del mapa nacional tras su fracaso rural.

Narrado paródicamente, el fracaso de los ascendientes de la protagonista durante su proceso de inventarse una nación cumple en el relato una función metafórica eficaz.

Al final de los años del Virreynato del Río de la Plata, su tatarabuela María Teodora de Vera y Mujica y López Pintado le descubre a su esposo que su pretendido linaje de descendiente de conquistadores y adelantados mestizados con la raza vencida está mancillado con sangre impura. A pesar de sus expediciones contra los indios charrúas, guaraníes y 
mocovíes, con quienes tuvo descendencia indígena, hubo un subrepticio antepasado judío portugués en su familia: Manuel Lobo, de la Colonia de Sacramento, cuya sangre se mezcló en su imaginario linaje de pura cepa hispano-americana católica. Al despuntar el crucial año 1810 de la emancipación americana, los Torre y Vera y Mujica en Entre Ríos ocultaban que en sus venas corría sangre de sus víctimas quemadas, torturadas y asesinadas. Desde los albores de la nacionalidad, pues, estos criollos patricios que se inventan un linaje nacional eran descendientes promiscuos de inquisidores, de charrúas: incluso de marranos.

Pero también el lugar donde confluyó la sangre de los Ortiz y los Oderigo al igual que los Dujovne, fue una comarca de confluencias geográficas. Entre Ríos: tierra de tránsito y de ríos que comunican espacios distintos, cruzadas por fronteras imprecisas donde habitan heterogénos pueblos con tribus autóctonas. La provincia de Entre Ríos imaginada por Alicia es una tierra litoral donde sus antepasados conviven con perseguidores y perseguidos, y su naturaleza fluvial comprendía a los ríos Paraná, Uruguay, pero también al Volga y al Guadalquivir. Su antepasado genovés Oderigo fue protagonista principal de la gesta clave de la formación de la nacionalidad cuando luchó en pro de la libre navegación de los ríos. Al modo de sus aguas que alfuyen, confluyen y se mezclan en sus afluentes hasta desembocar juntas en el delta, también los antepasados surgen y generan los relatos que la narradora remonta en una memoria hecha de girones que no dejan espacio a la tierra firme (113).

Cuando llega Giuseppe Oderigo en 1826 descubre que, “vista desde aquel río pardo, Buenos Aires se confundía con la pampa” (116) y la ciudad y la ribera eran un paisaje todo mezclado. Oderigo recuerda:

—Allá (Génova) la tierra era de tierra, el mar, de mar, y el aire, puramente de aire ... En cambio, acá, todo esta mezclado: una tierra fofa, una agua barrosa y un aire húmedo y espeso donde flotan gotas y motas ... En Génova, hay dos modos de irse. Uno desaparece de pronto tras la roca, como quien muere de golpe, o se va por el mar, en lenta agonía. Aquí, en cambio, lo único que queda es alejarse "como quien se desangra" (117).

Resulta muy significativo que la primera imagen cartográfica sobre las provincias del Litoral argentino que le impresionó al antepasado genovés por vía materna de la futura exiliada en París fuese un “cuerpo trunco, sin brazos ni piernas”. Es decir, la imagen de un cuerpo decoyunturado: "El tronco descuartizado avanzaba oblicuamente con un hombro antes que el otro. A diferencia de las demás provincias, que se quedaban cada una en su sitio, ese tronco sobre el mapa hablaba de confluencias y de viajes” (117).

Hasta llegar a su destino, Giussepe Oderigo va descubriendo imágenes desterritorializadas de la joven nación sudamericana. El fluir sin recuerdos es una temprana imagen que le inspiró la naturaleza fluvial de las provincias litoraleñas. Navegando sobre el ancho lomo dorado del Paraná “comprendió que era un viaje al olvido”, donde se “extraviarían sus orígenes por esos vericuetos”. Sintió que vivir en ese lugar iba irremisiblemente a condenar al olvido a todos sus familiares Oderigo, oriundos de la costa ligur, "mientras el Paraná fluía enorme con su piel erizada, río desmemoriado, río para borrar y perder”. Pero con esta imagen visual, se superponía otra imagen olfativa y mucho más persistente: el olor a matadero de ganado, "inmenso y doliente mugido agigantado con el 
viento”. Desde entonces, el olor de la provincia de Entre Ríos huele nauseabundo para Oderigo: hedor de vaca muerta. No el olor de alimento vacuno, sino a deguello animal que se confunde también con sangre humana: "Ya desde el barco y sin pisar tierra había comprendido que la pasión argentina era el deguello" (127).

La otra imagen del nuevo país de Oderigo era la de los caudillos que oponían sus intereses regionales a los nacionales, y pretendían ostentar un abolengo criollo sin mezclas. Pero los Rivadavía, Rosas, Urquiza, Mitre, a pesar de sus diferencias, nacieron de cruzas étnicas que formaron las oligarquías vestidas de ponchos indios y galera inglesa, dueños de esos "países bastardos, que se creían limpios de sangre”. Los viajes de Oderigo en goleta desde Buenos Aires hasta Asunción les sirvieron para descubrir solo la imagen de una nación fragmentada, hipócrita y egoísta, mientras "pasan los ríos por esas tierras fugitivas" (137), donde los tanos y patricios se amancebaban con indias y los italianos buscaban acriollarse rápidamente, mientras que las esposas de sus parientes estancieros de entrerrianos, como Josefa Fihs, “con su pelo de irlandesa y su culo de negra”, (....) preferían meterse dentro de una historia en la que todo fuese claro (169).

Sin embargo, la historia entrerriana, lejos de ser todo claro, resultó muy confusa y mezclada por sangres de indios, gauchos, pardos, aventureros europeos, inmigrantes italianos, suizos y judíos. La madre de la narradora, Alicia Ortiz Oderigo, era la hija del nieto de Toribio Ortiz, quien se casa con un hijo de colono judío, Carlos Dujovne, nacido en las colonias agrícolas del Baron Hirsch. Su abuelo, el patricio estanciero Manuel Ortiz de la Torre e Iturri Vera y Mujica, decepcionado de que sus hijos se fueran a la ciudad, en un rapto de depresion firmó un testamento donde deshereda a sus hijos legítimos para ceder todas sus estancias a los hijos del inmigrante administrador irlandés de sus campos. Este Ortiz que tanto ayudó a Urquiza para evitar la derrota en la batalla de Pavón, se constituye finalmente en otra imagen de derrota del país: el ciudadano dividido cuya otra mitad constantemente dice adiós (176).

Pero también dirán adiós a la nueva nación algunos extranjeros recién llegados a la Argentina, judíos entre ellos, convocados por el libérrimo preámbulo de la Constitución Nacional del país que buscaba la contribución masiva de los inmigrantes europeos para su modernización. No todos los colonos judíos que llegaron a Entre Ríos de KamenevPodolski lograron territorializarse en la nueva Sión reencontrada en los campos de la JCA. El abuelo de la narradora por vía paterna, don Samuel Dujovne, nada tiene en común con Los Gauchos Judíos (1910) de Alberto Gerchunoff, ese mítico emblema literario del Centenario sobre la argentinización de los inmigrantes. Para todos los inmigrantes agricultores judíos, el trabajo agrícola en las tierras de las colonias de la JCA fue la carta de nacionalización, el pasaporte orgulloso de la nueva identidad cívica obtenida por los nuevos campesinos integrados a la Nación imaginada por Gerchunoff quien aprendió de memoria los endecasílabos con que Rubén Darío y Leopoldo Lugones componían sus églogas a la argentinidad. Sin embargo, a pesar de que Samuel Dujovne llegó a Colonia Carmel huyendo de los pogroms de la Rusia Zarista, nunca logró sosiego espiritual en las pampas entrerrianas, ni quiso territorializarse en su nueva patria. La parábola de su dramática vida narrada en El árbol de la gitana es la contracara de la narrativa "gerchunoffiana” de la identidad cívica del judío. Porque el abuelo de la narradora simboliza, básicamente, la dificultad de vivir dentro de fronteras nacionales. Colonia Carmel era un punto en la 
vastedad insoportable del paisaje entrerriano donde el maestro e intelectual Samuel Dujovne no lograba sobrevivir. Vacío sin límites, la nueva tierra le daba vértigo al inmigrante ruso que nunca se sintió en su nuevo hogar.

"Colonia Carmel era un sitio que lanzaba las cosas al voleo, apuntando a lo lejos en un intento por atrapar aquella franja de nada que parecía retroceder a cada paso". Samuel, a diferencia de los otros gauchos judíos, nunca supo maniar una vaca ni montar a caballo. Tal vez porque en la exasperación de ver cómo el horizonte siempre retrocedía a medida que avanzaba, temía enloquecer pensando que ni a galope tendido lograría alcanzar el final del horizonte (197).

No sólo las plagas naturales de langostas y la inclemencia de los campos molestaban a Samuel Dujovne: tampoco conseguía acriollarse. Y a diferencia de los gauchos judíos de Gerchunoff, "nunca accedio a torcer la cadera. Seguía caminando por la pampa como por Besarabia o Moldavia, donde, por lo demás, jamás había pisado otra cosa que libros”. Y cuando en 1903 nació su hijo, no quiso darle el nombre de Akiba, sino el de Carlos, porque “mejor era un nombre sin historia ... para no cagarle la existencia en Argentina” (202). Finalmente, Samuel y su primogénito ese año abandonan Colonia Carmel para radicarse en Córdoba.

Esta dificultad del abuelo de vivir sobre la tierra porque la inmensidad de la pampa le producia vértigo, constituirá un recuerdo familiar anclado muy profundo en la memoria de la nieta. Desde entonces, igual que a su abuelo, le obsede a la narradora develar el enigma de si huir de la tierra es coraje o cobardía, torturándolo(la) toda su vida hasta con intentos suicidas. Es el mismo enigma que Samuel volverá a formularle a su hijo Carlos, el padre de Alicia, cuando a los 18 años abandona su tierra argentina para vivir en la URSS, después de fundar el Partido Comunista de su país. "Habrá pensado Samuel, al despedir a su hijo, que el verdadero regalo de la Historia no estaba en la Argentina sino en Rusia” (203-204), pregunta la narradora para responderse inmediatamente: "Lo habrá pensado, sí. Amargamente. Es fácil adivinarle el pensamiento. Uno no sólo se equivoca de esperanza, también se equivoca de frustración” (203-204).

Es la misma frustración que entristece al otro antepasado del árbol genealógico, el terrateniente Ortiz, al decidir donar todas sus estancias porque, como dice la Gitana, “El Que Nos Suea no avanza en línea recta y a veces la orden de vivir se la imparte al de al lado. En toda vida hay un oscilar marinero que va de mí a vos y de vos a mí. Y la mitad de cada uno ha de decir constantemente adiós ....” (205).

Si el abuelo Samuel se equivocó de frustración, su hijo Carlos Dujovne se equivocó de esperanza, afirma la narradora. Ambos imaginaron una Nación muy diferente de la que ofrecía la Argentina en la primera mitad del siglo. Las esperanzas sucesivas y desfasadas de la realidad del país, nos permiten saber cómo Carlos imaginaba la Nación mientras la hija recuerda en flashes cinematográficos la larga agonía de su padre en un hospital de Buenos Aires.

La primera imagen era la de un niño de seis años viviendo aislado en una colonia agrícola de la JCA de Entre Ríos. “Hablaba únicamente idish, entendía el ruso y vivía en un país de judíos atravesado al galope por hombres emponchados que también lo miraban como aquella víbora”. Luego, cuando su familia abandona la colonia y se van a vivir a Córdoba, "la mudanza lo convirtió en extranjero", al descubrir en ese centro urbano a los niños 
argentinos que hablaban el castellano y ante quienes les mentía acerca de su origen familiar: "El inmigrante está obligado a mentir porque su propia historia suena exagerada. El sonido de las mentiras no es menos estruendoso, pero al natural del país, sea éste cual fuere, los relatos verídicos le producen una curiosa desazón y, para no tener que enfrentarse con una vida distinta de la suya, prefiere que se le mienta” (240).

Desde los 11 años vivirá con su tía en Haedo, suburbio de la capital federal, y desde la trastienda de la farmacia se imagina un país muy distinto de lo que fue y sigue siendo. Subido a la escalera, Carlitos estaba suspendido entre dos mundos, "enfrenta las guitarras de una Argentina moribunda, y le dá la espalda a un violín gitano y judío que serpentea por su médula, pero lejos, muy lejos y asimismo perdido”. En esa localidad suburbana provincial, conoció a los arrieros que iban a Mataderos a llevar el ganado y durante las noches los últimos payadores se reunían en torno a un fogón a cantar sus adioses. "A ellos, la pampa que a Samuel le parecía tan grande se les está achicando. Ya no queda lugar para sus largas, interminables milongas, ni para sus ilimitadas cabalgatas” (241).

Pero también en Haedo conoció a los anarquistas vegetarianos y a militantes comunistas que se imaginaban otra Nación. La conversión de Carlos al comunismo constituyó un nuevo nacimiento: abandonó todo, desde el colegio Nacional hasta "mil quinientos años de tradiciones sagradas”. En 1918 Carlos tenía quince años y figuraba entre los fundadores del Partido Comunista: aunque "en el fondo de su alma se llamaba Akiva pero decía llamarse camarada Carlos". A los 18 años se fue a la URSS, desandando exactamente el camino inmigratorio de los Dujovne, "porque el viaje de los padres le parecía un error”. La primera desilusión que sufrió Carlos de la utopía comunista ni bien llegó a la URSS tuvo que ver con su nacionalidad. Inexplicablemente, este joven que abrazó el internacionalismo proletario no entendió por qué el policía fronterizo que controlaba los pasaportes, brutalmente le reveló que la verdadera nacionalidad de Carlos Dujovne no era la argentina, como alegaba su pasaporte, sino la judía: “serás ciudadano argentino — le dijo el policía, súbitamente serio, —-pero de nacionalidad judía” (244).

El origen "nacional judío y no argentino" de su ser, súbitamente descubierto en la URSS, será archivado en el desván de la memoria de Carlos, quien "lo registró en su subconciente y nunca terminó de elaborarlo del todo”, como dice la narradora. Disciplinado comunista, nunca quiso Carlos aceptar la versión cívica de los Dujovne sobre el ser judeoargentino en las pampas entrerrianas de las que huyó su padre, y menos aún la versión soviética que reconocía como nacionalidad a la minoría judía en la URSS. Pero el camarada disciplinado Carlos tampoco quiso reconocer durante años la sangrienta represión stalinista contra los intelectuales judíos disidentes en la URSS acusados de trotskistas y sionistas, entre ellos a su propio primo moscovita Ben Sion Dujovne, liquidado junto a los grandes escritores como Radek, Kamenev y Zinoviev a quienes conoció personalmente en los años del NEP. Cuando el camarada Carlos se encontró personalmente con Stalin en ocasión de acompañar al escritor Henri Barbusse, el líder soviético se negó a dar fe de las proclamadas dos identidades de Akiba/Carlos: Stalin no quiso creerle que fuese argentino ni hijo de judíos rusos. Para su desilusión, el jerarca lo confundió con un rumano gitano porque no conocía bien ni el idioma ruso ni el francés para oficiar de intérprete de Barbusse cuando vino a los festejos del X aniversario de la Revolución (254). Luego de regresar a América Latina al cabo de cinco años en Moscú donde se graduó en Ciencias Sociales y Diplomacia, 
Carlos ejercerá su nueva identidad internacionalista atravesando las estrechas fronteras nacionales de su país de nacimiento. Para empezar, va a entrar con un pasaporte falso y su nombre cambiado fue Carlos Fuentes porque era desertor del ejército argentino. Su primera misión la cumplió en Montevideo donde le encomendaron dirigir el Buró Sudamericano de la Internacional Sindical Roja. Después intervendrá en el frustrado conato revolucionario de Marmaduke Grove en 1932 en Santiago de Chile, con apoyo de la marina sublevada. Huirá, finalmente, a la Argentina donde militará en la clandestinidad, y pasará temporadas entre cárceles y células de base del PC. Incluso va a participar de la revolución boliviana como planificador de la reforma agraria invitado por el Movimiento Nacionalista Revolucionario de Paz Estensoro.

Es que a pesar de haber decidido volver a la Argentina y dejar de ser ciudadano de la URSS, Carlos reemplazó jubilosamente la Nación por otra: “el PC es un país”, recuerda la hija narradora. La tardía decisión de su padre de abandonar el Partido Comunista Argentino fue mucho más que una ruptura política con el amor de su juventud: representó un doloroso destierro que no pudo soportar y murió sin esperanza. Gracias al trabajo de la memoria de la narradora conocemos este sentimiento de extranjería que también recibió su hija de legado:

Finalmente, (...) abandonó el PC sabiendo que lo acusarían de traición. El PC es un país. El que se marcha del PC se vuelve extranjero. La hija se crió en el extranjero por ser de padres desterrados de Rusia, de Génova, de España, de Entre Ríos y del PC (267).

Desde entonces, Carlos sobrevivió como un extraño en Buenos Aires, trabajando de obrero en una fábrica de caramelos. No sorprende que el sentimiento de extranjería sea la metáfora más fuerte que recorre el árbol genealógico de la exiliada judeoargentina en París. Antes de su exilio, y mucho más intensamente después, Alicia parece ir desapegándose de su Nación a medida que hurga en la memoria colectiva familiar y remonta los mojones de esa singular estirpe de exilios con antepasados paternos descendientes de Juzaros, jasidim y del pogrom de Kishinev, junto a sus ancestros maternos de inquisidores, marranos, indios y navegantes genoveses.

Muy significativamente, la decisión de Alicia de escribir ese pasado familiar tan heteróclito fue tomada en el momento de acompañar a su padre moribundo. Así, en la despedida postrera del hospital, la hija se prometió escribir(le) las memorias inconclusas a(de) su padre y también las de su abuelo suicida: “Acababa de echarme a las espaldas el bulto de su historia... Yo heredaba una cadena de memorias sin hacer. Ristras de anécdotas deshilvanadas que perdían sentido a fuerza de ser contadas ...” (277), confiesa la narradora a su madre.

Pero además, la memoriosa narradora se echará también el bulto de la historia de los antepasados de su madre, descendiente de inquisidores, navegantes, indios y capitanes, pero sobretodo heredera de historias sin contar y de numerosas casas ausentes con sus artefactos perdidos. La figura de la madre está más presente en la novela por el relato de sus ancestros que por su transformación en personaje. Sin embargo, toda la novela de Alicia Dujovne Ortiz está escrita con el lenguaje de la madre para poder contar la memoria colectiva de sus linajes. La hija hereda de su madre el sentimiento de la desmesura al mismo tiempo que el 
sentimiento de la Argentina profunda de los Ortiz entrerrianos. En los momentos graves la vástaga de terratenientes desheredados se parece a una india serena e insondable, pero su estado casi natural era transmitirle a su hija una profunda ansiedad porque le "quedaba chica la pampa”. Tal vez por eso, en vez de imaginarse las comarcas telúricas de su Nación como otras escritoras entrerrianas, el sueño de la madre escritora fue siempre transponer las fronteras provinciales y nacionales. ${ }^{8}$ No extraña entonces que desde muy joven la madre haya sido comunista e internacionalista, y en vez de escribir sobre la provincia de sus ancestros, quiso ser una intelectual afrancesada en Buenos Aires porque amaba a Musset y Turgueniev, y consagró toda su vida a escribir veinte tomos de la historia de la literatura europea del siglo XVIII y XIX.

Resulta paradigmático que las desmesuras culturales europeas maternas y las utopías sociales paternas, se rescaten en el tiempo de la memoria de mezclas de "gente tan distintas" (278), que sólo logran confluir en la tierra de Entre Rios. La provincia de los estancieros Ortiz y de los gauchos judíos se transforma en un lugar contradictorio y fundamental de la memoria colectiva: es el lugar de la tierra y de su pérdida. La imaginación cartográfica de la narradora transfigura a Entre Ríos en el oxímoron de la Nación: en esa tierra sus antepasados buscaron territorializarse pero, a la vez, rápidamente la abandonaron. Desde hacía muchos años que ni la madre ni ninguno de sus ancestros residían en la provincia del general Urguiza. En el mismo momento de la despedida de su padre, apareció el mapa de la provincia proyectado en la sala del hospital con la forma "del cuerpo de nadador sin brazos” atravesando los ríos Paraná y Uruguay, pero también junto a "otros ríos de nombres extranjeros, cabalgatas y pasos”. En ese momento comprendió que en realidad estaba viendo "el mapa del tiempo" y no una topografía. Vio: “el mapa de la tierra que no tuve debido a una congoja y a un suicidio" (277).

Entre Ríos es el oxímoron del descentramiento del sujeto nacional de la narradora ciudadana y de sus fragmentos, pero sobre todo de las confluencias del hato de fantasmas familiares: “de inquisidores y quemados, indios y capitanes, judíos y cosacos” (280). Oxímoron de la tierra nacional de "perdedores, fracasados,vencidos, desterrados" (279). Entre Ríos configura el oxímoron de una Nación con fronteras desdibujadas donde todos sus antepasados perdieron algo valioso: María Teodora, la limpieza de sangre, Giuseppe, su flotilla de barcos; Manuel, todas sus tierras; Samuel, su vida; Carlos, el comunismo. Cuando la hija angustiada quiere exiliarse descubre el verdadero sentido familiar de ese oxímoron, y le confiesa a la madre su miedo de invertir el camino de sus ascendientes: "Durante siglos y siglos, ustedes se han ido dando cita en Entre Ríos. Este es un país de mezclados, un revoltijo de sangres que se fue cocinando con tiempo. Si yo me voy de la Argentina - y ya lo veo que me voy.., pondré patas arriba una corriente. No seré castigada por invertir la marcha?” (281).

\footnotetext{
${ }^{8}$ En este sentido, una lectura posible de El árbol de la gitana se puede hacer exactamente en el revés de la trama novelística de imágenes de la Nación tal como surgen de textos de la escritora entrerriana de madre judía María Esther de Miguel. Ver, por ejemplo, sus novelas Espejos y Daguerrotipos, Los que comimos a Solís, Calamares en su tinta. Leer también su texto autobiográfico "Ser Judío en mi país” y confrontarlo con las declaraciones autobiográficas de Alicia Dujovne Ortiz en la entrevista con Leonardo Senkman.
} 
Efectivamente, la exiliada judeo-argentina en París siempre se sintió castigada adentro suyo (225). Quizá por eso, aun después que su país haya recuperado la democracia y la Nación Republicana haya puesto fin a los años aciagos de represión del Estado Autoritario que la forzó a ser una exiliada, la narradora decide vivir fuera de su tierra natal, obedeciendo más el mandato de su memoria colectiva recuperada, que a su libre voluntad. A diferencia de otros exiliados que rumiaban todo el tiempo el sueño del retorno a la Nación, a Alicia nunca le interesaba como a ellos "estar lejos de la patria para entenderla mejor” (225). Por el contrario, descubre en la errancia y el vivir entre fronteras nacionales como destino concientemente aceptado, una suerte de castigo por el cual "hay que seguir pagando hasta que Él lo disponga” (225), en la mejor tradición religiosa nacional del Galut (destierro) judío.

A pesar de su aire juguetón y levemente frívolo, El árbol de la gitana es una de las novelas sobre la condición de extranjería más radical que produjo la reciente literatura del exilio argentino. Y no sólo por el significativo hecho de que su publicación francesa haya precedido a la argentina. Lo nuevo es que el libro de Alicia Dujovne Ortiz se inscribe en otro andarivel del ciclo de la novelística de la memoria escrita desde el exilio. Pedro Orgambide, también exiliado político judeoargentino de los años 70, escribe sobre un matiz diferente de la extranjería que Dujovne Ortiz. Al igual que la exiliada en París, vivir en México fue para Orgambide un exilio que "le había servido para entender un poco más a quienes un siglo antes habían descendido de los barcos huyendo de la pobreza y de la intolerancia. Ella era nuestra memoria y nuestra genealogía”. Pero a pesar de coincidir con Dujovne Ortiz en desandar el camino de sus abuelos inmigrantes, y repetir igual que ellos las dificultades de adaptación cultural y lingüística, la voz del extranjero argentino en México se mitigaba de un modo diferente que la exiliada en París. Así, Orgambide se consolaba con la frecuentación de otros lenguajes y la peregrinación urbana de mercados y cantinas donde hallaba voces similares al tango en boleros y corridos. El autor de Pura Memoria soñaba con su nación y se la imaginaba incluso en el habla popular de México. Y si Orgambide experimentaba que “esa música verbal no era mía”, y comprendía fuera de su país que “un mismo idioma nos separaba”, sin embargo nunca sintió como Dujovne Ortiz que había perdido la lengua de Buenos Aires, ni menos aún que perdió a su patria. ${ }^{9}$

La extranjería del texto de Dujovne Ortiz básicamente expresa de un modo radical la condena de Ulises escrita con la lengua materna (no de su ciudad) sobre los lugares que duelen a la memoria familiar. El árbol de la gitana no sólo narra la dolorosa separación de la patria que le permite entender mejor la genealogía de sus antepasados inmigrantes, sino es una aguda reflexión de los viejos y nuevos límites entre los “nuestros” y los “otros” y una interrogación sobre la identidad colectiva fracturada.

La pérdida de la Nación intenta ser recuperada por la memoria colectiva en su esfuerzo de inventarse y hacer inteligible un pasado propio aunque no coincida necesariamente con la historia de su patria, antes y después de la dictadura militar. Aquí yace la gran diferencia

\footnotetext{
${ }^{9}$ Véase Pedro Orgambide (“La voz del extranjero”). Orgambide confiesa que su extranjería le hizo comprender mejor el idioma del cocoliche del sainete y de los arrabales del lunfardo de Buenos Aires; también su extranjería le hizo recordar las perplejidades lingüísticas que sentía Alfonso Reyes hablando con Jorge L.Borges en Buenos Aires "del mismo idioma que nos separa".
} 
en el uso de las genealogías familiares de la novela de Dujovne Ortiz respecto de otros autores judeoargentinos y latinoamericanos.

De algún modo, la novela Hacer la América de Pedro Orgambide fue un intento de reconciliar su memoria familiar con la historia de la inmigración aluvial de la Argentina; análogamente, Mestizo de Ricardo Feierstein ${ }^{10}$ ensayó expresar el fin de la otredad de un exiliado interior de la dictadura y la marginación de cuatro generaciones de inmigrantes judíos, cuando en 1983 por primera vez se siente parte de una mayoría nacional mestizada culturalmente gracias a la democracia recuperada. También Feierstein construye su novela para descubrir su pasado en torno al árbol genealógico familiar; pero a diferencia del narrador de Mestizo, la narradora de El árbol de la gitana no se consuela con descubrir que también su Nación configura un mestizaje de familias, orígenes y religión tan heterogéneo como su propia biografía. Ella desde siempre supo de su condición mestiza: medio judía para los cristianos, medio cristiana para los judíos. Recién a partir del exilio podrá ver su árbol no con los ojos de la nación acrisolada, sino con la mirada de la Gitana, esa nómade errante. Mientras que el árbol de Feierstein le ayuda a construir una identidad en la mezcla imaginada del nosotros de una ciudadanía recuperada por la ilusión de participar de una sociedad civil pluralista, la memoria de Dujovne Ortiz le descubre irremisiblemente el sentido de su vida fragmentada. Como si funcionara también de oráculo y ángel de la guarda, la voz de la gitana le muestra a la narradora que para poder avanzar más allá de la nación, “ el corazón ha de estar en pedazos” (293). Tal como estuvo en pedazos el corazón de su familia transhumante en todos los lugares de la memoria que le contó la Gitana a la narradora para "hallar el hilo del sentido" de cruzar la diacronía de los Dujovne y los Ortiz con la sincronía del "Caucaso, el mar Caspio, Crimea, Besarabia o Moldavia, KamenevPodolski, Géneva, Toledo, Jerez de la Fontera, Islas Canarias, Entre Ríos ...” (23).

No casualmente la novela se cierra en un epílogo que lleva el nombre de las dos tierras prometidas, El Dorado y Jerusalem, para contar la metáfora del corazón fragmentado en pedazos muy lejos de los contornos nacionales.

\footnotetext{
${ }^{10}$ La idea del mestizaje cultural del judío argentino es profundizada por Feierstein en otro ensayo, "Todas las culturas, la Cultura” (Contra-exilio y mestizaje), donde intenta mostrar la posibilidad de incorporar la identidad de los inmigrantes y sus descendientes en un árbol genealógico retocado según el modelo de Ricardo Rojas en su Amerindia. Feierstein intenta escribir, desde lo judío, una literatura mestiza pero con la misma retórica del mestizaje cultural que buscaba canonizar un discurso híbrido, heteróclito, para crear la ilusión de síntesis y homogeneidad lingüístico-cultural sin supuestos conflictos entre mayorías y minorías. Su libro se inscribe en la vuelta a la democracia argentina que introdujo en el campo cultural el concepto de pluralismo; el cual, a pesar que reconoce las diferencias, garantizaría relegitimizar las identidades colectivas sin apelaciones a alteridades y marginalidades de grupos minoritarios. Precisamente la crítica al discurso literario del mestizaje apunta a denunciar su incapacidad textual para que aflore la complejidad histórica y antropológica de la hibridez cultural, las dolorosas tensiones interculturales y conflictos interétnicos en América Latina. Véase Alberto Rodríguez Carucci. El proyecto discursivo de Feierstein tiene como antecedente el libro de Margo Glantz, Las Genealogías que pretende integrar la identidad judía en el estatuto del mestizaje cultural mexicano.
} 
Agosín, Marjorie. Dear Anne Frank/Querida Ana Frank. Washington, DC: Azul Editions, 1994.

Sagrada memoria: reminiscencias de una niña judía en Chile. Santiago: Cuarto Propio, 1994.

Brailovsky, Antonio Elio. Identidad. Buenos Aires: Sudamericana, 1980.

Campos, Haroldo de. O sequestro do Barroco na formação da literatura brasileira: o caso Gregorio de Mattos. Salvador, Bahia: Fundação Casa de Jorge Amado, 1989.

Carucci, Alberto Rodríguez. "Discursos literarios y retórica del mestizaje”. Estudios 4/8 (Caracas, 1986): 42-51.

Costantini, Humberto. En la noche. Buenos Aires: Bruguera, 1985.

De dioses, hombrecitos y policias. Buenos Aires: Bruguera, 1989.

Rapsodia de Raquel Liberman (manuscrito inédito, 1990).

Chejfec, Sergio. Lenta biografía. Buenos Aires: Puntosur, 1990.

Dujovne Ortiz, Alicia. El árbol de la gitana. Buenos Aires: Alfaguara, 1997.

Feierstein, Ricardo. Mestizo. Buenos Aires: Mila, 1989.

“Todas las culturas, la Cultura”. Contraexilio y Mestizaje. Ser Judío en la Argentina.

Buenos Aires: Mila, 1996. 109-158.

Fingeret, Manuela. Hija del silencio. Buenos Aires: Planeta, 1999.

Futoransky, Luisa. Partir, digo. Valencia: Prometeo, 1982.

Son cuentos chinos. [1983]. Buenos Aires: Planeta, 1991.

De Pe a Pa. Barcelona: Anagrama, 1986.

La Sanguina. Barcelona: Taifa, 1987.

Urracas. Buenos Aires: Planeta, 1992.

La parca, enfrente. Buenos Aires: Libros de Tierra Firme, 1995.

Cortezas y fulgores. Albacete: Barcarola, 1997.

Formosa (novela inédita, 1999).

Gelman, Juan. Com/posiciones. Barcelona: Libres del Mall, 1984.

Dibaxu. Barcelona: Seix Barral, 1994.

Interrupciones I. Buenos Aires: Seix Barral, 1997.

Interrupciones II. Buenos Aires: Seix Barral, 1998.

Incompletamente. Buenos Aires: Seix Barral, 1997.

Glantz, Margo. Las Genealogías. México, DF: Martín Casillas, 1982.

Goloboff, Gerardo Mario. Criador de palomas. Buenos Aires: Bruguera, 1984.

La luna que cae. Barcelona: Muchnick, 1988.

El soñador de Smith. Barcelona: Muchnick, 1990. Comuna Verdad. Barcelona: Muchnick, 1995.

Jelin, Elizabeth. "The Politicas of Memory: The Human Rights Movements and the Construction of Democracy in Argentina”. Latin American Perspectives 21/2 (1994): 38-58.

Liberman,Arnoldo. Grietas como templos. Biografía de una identidad. Madrid: Altalena, 1984. 
Miguel, María Esther de. Espejos y Daguerrotipos. Buenos Aires: Sudamericana, 1980. Calamares en su tinta. Buenos Aires: Editorial Losada, 1968.

Los que comimos a Solís. Buenos Aires: Sudamericana, 1965.

"Ser judío en su país”. El Imaginario Judío en la literatura de América Latina.

Patricia Finzi, et al. Buenos Aires: Grupo Shalom Editor, 1990.

Mercado, Tununa. En estado de memoria. Buenos Aires: Ada Korn, 1990.

Mongin, Oliviere. “Une Memoire sans Histoire?” Esprit 3-4 (Mars-Avril, 1993).

Nora, Pierre. Les Lieux de memoire II: La Nation y III: La France: Paris: Hachette (19861992).

Orgambide, Pedro. Aventuras de Edmundo Ziller en tierras del Nuevo Mundo. México:

Grijalbo, 1977.

El arrabal del mundo. Buenos Aires: Bruguera, 1983.

Hacer la América. Buenos Aires: Bruguera, 1984.

Pura memoria. Buenos Aires: Bruguera, 1984.

“La voz del extranjero”. Clarín, cultura y nación (6 de junio de 1996): 14.

Oliveri,Marta. Memorias del ángel caído. Buenos Aires: Legasa, 1993.

Roniger, Luis y Mario Sznajder. The Legacy of Human Rights Violations in the Southern Cone: Argentina, Chile and Uruguay. Oxford: Oxford University Press, 1999.

Rosencof, Mauricio. Die Briefe Die Nie Angekommen Sind. Salzburg und Wien: Residenz Verlag, 1997.

Y nuestros caballos serán blancos. Montevideo: Arca, 1985.

"Literatura de calabozo". Represión, exilio y democracia: La Cultura Uruguaya. Saúl Sosnowski, comp. Montevideo: Universidad de Maryland y Ed.Banda Oriental, 1987. 127-140.

"Las cartas que no llegaron” (fragmentos), Marcha (Montevideo, 20 de junio de 1995): 6-7.

Sábato, Hilda. "Historia reciente y memoria colectiva”. Punto de Vista (Buenos Aires, agosto 1994): 30-34.

"Olivar la memoria”. Punto de Vista (Buenos Aires, diciembre, 1989): 6-9.

Senkman, Leonardo. “Entrevista a Juan Gelman”. Noaj 7-8 (1992): 106-115. “Entrevista a Alicia Dujovne Ortiz”. Noaj 2 (1988): 87-92.

Sillato, María del Carmen. “Com/posiciones de Juan Gelman o cómo traducir los mil rostros de la realidad”. Hispamérica 72 (1995): 3-14.

Sosnowski, Saúl. Represión, exilio y democracia: La Cultura Uruguaya. Montevideo: Universidad de Maryland y Ed. Banda Oriental, 1987.

Represión y reconstrucción de una cultura: el caso argentino. Buenos Aires: Eudeba, 1984.

y Jorge Schwartz (orgs.). Brasil: O Transito da Memoria. São Paulo: Editora Universidade de São Paulo y Universidad de Maryland, 1994.

Strejilevich, Nora. Una sola muerte numerosa. Miami: University of Miami, 1997.

Telaak, Anastasia. "Reseña bibliográfica a Die Briefe Di Nie Angolkomen de M. Rosencof. Noaj 12-13 (1997): 162-166.

Vásquez, Ana. Abél Rodríguez y sus hermanos. Barcelona: La Gaya Ciencia, 1981. y Ana María Araujo. Exils Latino-Americains: La Malediction D’Ulysse. París: CIEMI L’Harmattan, 1988. 
Vásquez Bronfman, Ana. Las jaulas invisibles (novela inédita, 1998).

Mi amiga Chantal. Barcelona: Numen, 1991.

“De rupturas y distancias”. NOAJ 2 (1988): 60-63.

Vezzeti, Hugo. "Variaciones sobre la memoria social”. Punto de Vista (Buenos Aires, diciembre 1996): 2-4.

"La memoria y los muertos”. Punto de Vista (Buenos Aires, agosto 1994): 1-4.

Viñas, David. Cuerpo a Cuerpo. Buenos Aires: Siglo XXI, 1980.

Wechsler, Elina. Progresiones en un cierto mes de julio. Madrid: Verbum, 1995.

Mitomanías amorosas. Madrid: Verbum, 1991.

La larga marcha. Madrid: Editorial Playor, 1988.

El fantasma. Madrid: Montenegro, 1983. 